\title{
UTRPENÍ AKTUÁLNOSTI
}

BŘETISLAV HORYNA, Katedra filozofie, Filozofická fakulta Univerzity Konštantína Filozofa v Nitre, Nitra, SR

HORYNA, B.: Suffering of Topicality

FILOZOFIA, 74, 2019, No 5, 394 - 404

Essay describes the various opportunities in which to use the word timeliness. On the basis of three historically different opinions it shows how different and situationally dependent is the timeliness speech of philosophy. The aims of this speech do not come from the philosophy itself, but from the side purposes. Claims about the topicality of philosophy do not concern any philosophical value, but stem from the will and intentions of the authors. Therefore, timeliness cannot be one of the criteria of philosophy.

Keywords: Actuality - Philosophy - Ecology - Environment - Hoffmann - Adorno - Badiou - Žižek - Democracy - Political philosophy

\section{Úvodem}

V eseji Když je filosofie aktuální (Horyna 2019) jsem se snažil otevřít dle mého soudu velmi diskutabilní otázku, proč se určité genitivní filosofie vydávají za tzv. aktuální, co toto sebeztotožnění znamená a čeho chtějí jejich autoři dosáhnout. Termín ,aktuálnost“ patrně zprostředkovává nějakou další, dodatečnou hodnotu filosofickým (myslím nyní oborově k filosofii náležejícím) textům, aniž by ale taková hodnota byla zřejmá, ověřitelná či jakýmkoli způsobem prokazatelná. Je ,aktuálnost“ jenom fikce, verbalismus, používaný na základě důvěry v intuitivní rozumění toho, co se míní tímto výrazem? O co se snažíme, když ř́káme, že jsme aktuální? O upozornění na svou důležitost, významnost, nepominutelnost; o výzvu k následování, o získání přívrženců, o získání možnosti k nátlakovému přístupu; o varování před riziky, která mohou mít zničující dopady; o vyšší prodejnost svých knih, o vyšší popularitu v odborných i laických kruzích a s ní spojenou šanci na pozvání k přednáškám o daném aktuálním tématu; o nesmrtelnost; o implicitní odsouzení ostatních, zcela neaktuálních prací jiných autorů; o ještě něco jiného, co je dostupné jen zasvěceným? Nedokázal bych označit kterýkoli ze svých odborných textů za aktuální, protože jsem u každého z nich časem zjistil, že je jen novou variací na známý a již zpravidla několikrát zpracovaný problém. Jsem limitovaný šíŕkou a obsahem své imaginativní schopnosti - je právě toto chyba, která vede k důvodům, kvůli kterým se mně aktuálnost jeví jako prázdné slovní vyšperkování sdělení, jež mohou být zcela banální nebo „pomýlená“? A když jsem takto limitovaný já, můžu předpokládat, že to platí i o ostatních? Proti této úvaze nestojí nic, co by dokládalo její nemožnost; erarre humanum est, tj. když 
se mýlím já, s velkou pravděpodobností se občas mýlí i ostatní. Když se nemýlím, ve značně podobné míře se nemýlí ani ostatní. Když se neobejdu bez imaginace (a bez ní se neobejde nikdo, nejen ve filosofii, ale rovněž ve vědách), je to v míře, bez níž nemůžou být ani ostatní. Odkud se bere rozdíl, který našemu myšlení o filosofii vnucuje výraz ,aktuálni'“? Jaký máme důvod, abychom do filosofie vnášeli exkluzivizmus, odlišování podle fantaskních kritérií, vytváření žebříčků důležitosti, které odrážejí nanejvýš míru sociální inteligence autora? Co skutečně víme, abychom mohli stanovovat kritéria?

\section{O čem se mluví}

Pokusil jsem se o komparaci čtyř vystoupení filosofư k aktuálnosti filosofie se snahou srovnat předmět aktuálnosti, sílu jeho argumentačního zajištění, dobový ohlas a dějiny dalšího působení na filosofii, případně na veřejnost. Jde o pokus, tzn. o úkon spojený s vědomím rizik, zejména těch, které přináší komparatistika nejčastěji v podobě srovnávání nesrovnatelného. I to je sice možné bez opuštění oprávněně požadovatelné odborné úrovně (Antalík, 2005), rozhodně jednodušší je ale mít stále na mysli, že shody ve znacích ještě neznamenají shody ve významu, který jim lidé přisuzují.

První př́iklad tvoří nástupní přednáška profesora filosofie Franze Hoffmanna na místo rektora Univerzity Julia Maximiliana ve Würzburgu, přednesená 2. ledna 1858 pod názvem $O$ hodnotě a významu filosofie (Hoffmann, 1858). Další je rovněž nástupní přednáška, avšak Th. W. Adorna, u př́ležitosti propůjčení venia legendi na univerzitě ve Frankfurtu z 8. května 1930, pojmenovaná Aktuálnost filosofie (Adorno, 1990). Poslední dva př́ispěvky pocházejí od našich současníků, francouzského filosofa Alaina Badiou a Slovince Slavoje Žižeka, kteří se stř̌etli nad otázkou aktuálnosti filosofie v inscenovaném dialogu roku 2004 ve Vídni. Jeho výsledek byl vydán knižně pod názvem Filosofie a aktuálnost (Badiou, Zizek 2005). ${ }^{1}$

První, co zmiňuje F. Hoffmann ve své nástupní řeči, je pravda, kterou filosofie poznává. Př́istup filosofie k pravdě odůvodňuje spravedlivé očekávání, že bude společností uznána za nezbytný prostředek vzdělávání lidského ducha, protože vyšší stupně poznání se budou vždy odlišovat od nižších vyšším obsahem pravdy a vyšší úrovní vědomí, bez spoluúčinkování filosofie nikdy nedosažitelné. Filosofie se vždy setkávala s pochybnostmi ohledně možnosti jistého poznání pravdy, přesto však může snadno ukázat, že - za předpokladu nepředpojatého ducha - v takových pochybách setrvá jen člověk s nedostatkem poznání. Samo pochybování je totiž myšlením a myšlení v sobě předpokládá. Protože myšlení nemůže být myšlením ničeho, ale vždy zásadně něčeho, je také filosofii

\footnotetext{
${ }^{1}$ Knížka redigovaná $P$. Engelmanem vyšla o čtyři roky později v anglickém překladu a zřejmě pod vlivem ne právě vstřícných recenzí a kritik originálu pod významově značně posunutým titulem Philosophy in the Present (vyd. POLITY Press, Cambridge), který už nemusí nikoho pobuřovat jistě, i takhle může vypadat současná filosofie.
} 
vlastní myšlení něčeho určitého, které, je-li takto určeno ve své určitosti, nemůže být určeno jinak. K myšlení tak patř́ jistá nutnost, kterou filosofie umí formulovat jako ideální zákonitost myšlení, jež způsobuje, že každý zdravý a prèedsudky nezatížený rozum se cítí donucen uznat takový vztah mezi určitými pojmy, při němž je-li kladeno jedno tvrzení jako pravdivé, musí být současně kladeno také tvrzení druhé; tím právě uznává také rozdíl mezi zdůvodňujícím a zdůvodňovaným myšlením a s ním též mezi zdůvodňujícími a zdůvodňovanými pravdami, což ho zase dovádí $\mathrm{k}$ poznání, že bez zdůvodňujících pravd by nemohla být žádná pravda zdůvodněná. Je nezbytné, aby takové pravdy či alespoň jedna pravda existovala, jestliže má vůbec existovat pravda pro člověka a pro poznání pravdy.

Lidský rozum pritom osvědčuje svou schopnost poznat pravdu a rozlišit pravdivé od nepravdivého. I kdyby si mohl být jistý jen jednou jedinou pravdou, bude to pro rozum znamenat, že je schopen poznat nekonečně mnoho pravd; není totiž myslitelné, že by řǐše pravdy byla uspořádána tak, aby mezi jednou pravdou pro člověka a všemi ostatními pravdami zela nepřekročitelná propast. $Z$ toho pro Hoffmanna nutně vyplývá, že je možné a nezbytné překročit od poznání jedné pravdy ke všem ostatním, člověku v poznání dostupným pravdám, byt' je to práce pro nekonečně mnoho generací a na nezměrně dlouhou dobu, která vyžaduje splnění tolika podmínek, že jim člověk bude moci dostát až na věčnosti.

Filosofie tak dokazuje, že je schopná být skutečnou vědou, jak je vidno také z jejích tisíciletých dějin. Není imunní před omyly, ale svým vztahem k pravdě je chráněna před konstitutivním klamem a lží. Jako skutečná věda je nejen srovnatelná s jinými vědami, nýbrž je v některých aspektech překonává; matematika také poznává pravdu, ale pouze svou matematickou pravdu, která se zakládá na logice. V zásadě všechny vědy musí předpokládat logické pravdy, na nichž závisejí svou vědeckostí, nemohou vykročit z jejich rámce ani klást otázky směřující nad tento rámec. I tak však spolu s filosofíi neskonale převyšují zkušenostní poznání, jež sklouzává po povrchu věcí a zachraňuje svou slabost, nestálost a nejistotu znečistujícími fantaziemi všeho druhu. Pokud zkušenostní vědění někdy vyroste $\mathrm{z}$ dětských střevičků a stane se silnou vědou, bude to zásluhou osvojení filosofie, která svými geniálními výtvory rozšiřuje hranice lidského vědomí a vytváŕí metody poznání ve všech oblastech zkoumání. Až jsou zhotoveny, vtiskne je do dlaní ostatních věd a postoupí na další stupeň poznávání pravdy. Každý vyšší stupeň uskutečnění filosofie při poznávání pravdy tvoří a zdokonaluje její podstatu, která je principiálně neuzavřená, ale právě naopak, rozvijí se ke stále vyšším stupňům vlastního uskutečnění: taková je její prirozenost a zároveň úloha, kterou může plnit zásluhou obdivuhodné organizace německých univerzit, jejiž zásluhou se filosofii dostává nepominutelné moci při působení na všechny ostatní vědecké oblasti; filosofie má za sebou slavnou minulost, avšak na německých univerzitách ji čeká ještě slavnější budoucnost, kdy bude procházet perihéliem svého účinku na celek věd. 
Theodor W. Adorno pojal svou nástupní přednášku jako programovou řeč a přednesl pod názvem Aktuálnost filosofie koncepci filosofického výkladu jako rozumějícího zvýznamnění poznání věcí. $V$ poměrně konfrontačním duchu zhodnotil nejprve postoje dobově nejrozširřenějších myšlenkových směrů a škol (např. idealismu, novokantovství, pozitivismu, fenomenologie, filosofie života) a celý následující text zasvětil rozvedení své ústrední teze, podle níž se filosofie musí zbavit iluze, že prostřednictvím duchovní činnosti uchopí svět jako celek, jehož smysluplnost předpokládá a světu prrisuzuje; svět, včetně představy celku světa, už dávno leží v troskách. Idea bytí již nemá ve filosofii žádnou moc, zůstal z ní prázdný formální princip, jehož archaická důstojnost může halit jakýkoli obsah. Adornův projev nemá ráz sebeobhajoby, apologetiky vlastních názorů a ani př́sné kritiky ostatních filosofií; působí mnohem víc jako suché konstatování, jako sdělení, jak bude vypadat každý další hermeneutický krok filosofie při výkladu i těch nejtěžších záhad skutečnosti. Pokud něco obhajuje, pak požadavek, aby se filosofické výkladové modely vědomě přenášely do proměnlivých konstelací a v nich se osvědčovaly. Je to, jak říká, důsledek ztroskotání všech snah o velké a totální systémové filosofie, který klade prostou otázku - je dnešní filosofie vůbec ještě nějak aktuální? Aktuálností nemyslí jakousi na vágních představách o dané situaci založenou potřebnost, nutnost či nevyhnutelnost, ale zjištění, zda vǐči kladení filosofických otázek máme ještě přiměřenou možnost jejich odpovídání. Odpověd’ je negativní, protože jak starší, tak nejnovější dějiny kladení filosofických problémů dokládají principiální nezodpověditelnost kardinálních otázek. Každý, komu záleží na pravdě, vidí, jak filosofie směřuje ke své likvidaci: filosofii reálně hrozí, že se rozplyne v dílč́ch vědách, které, ačkoli samy nevystačí bez jistých předpokladů vycházejících z filosofie, jí samé nikdy neumožní, aby se stala „vědeckou filosofiiı“. Z filosofie nikdy nebude ,věda“, zato se bude muset pod tlakem empirických věd vzdát kladení otázek, které už př́sluší jim a které sama místo objasnění už jen zakalí. Se zapuzením těchto problémů rozhodně nesmí zpřetrhat svazky s jednotlivými vědami, které konečně navázala po staletích ignorování; naopak, protože jejich vytváření patří $\mathrm{k}$ největším výkonům moderní filosofie, musí je zachovat, mj. také proto, že konkretizované problémy poznání bude nucena $\mathrm{z}$ dílčích věd přebírat - sama už nemá prostředky na jejich pojmenování a zkoumání.

Filosofie se neodlišuje od vědy, jak se často naivně soudí, vyšší mírou obecnosti nebo abstraktnosti kategorií. Skutečný rozdíl spočívá $\mathrm{v}$ tom, že dílči vědy pochopí výsledky svého zkoumání jako konečné poznatky, tzn. jako něco akceptovatelného ve významu poslední danosti, kdežto filosofie $\mathrm{v}$ tomto bodě právě začíná. Je to pro ni první otazník, první znak, jehož záhadu může, dle vlastního mínění, vyřešit jen ona. Jednoduše řečeno, „ideou vědy je výzkum, ideou filosofie rozumějící výklad““(Adorno 1990, 334). V této tezi můžeme rovněž hledat klíč $\mathrm{k}$ Adornově důrazu na prověřování výkladových modelů v odlišných kontextech: je to obranná reakce na paradoxní situaci filosofie, která stále znovu a znovu vystupuje při svých výkladech s nárokem na poznání pravdy, nemá ale ani 
jeden nástroj, na který by se mohly její výklady spolehnout. Disponuje prchavými náhledy hádankovitých figur skutečnosti, jejich mizejícími odkazy a zázračným proplétáním, zauzlením či zasmyčkováním, v němž se jí dostávají na oči odkazy na skutečnost. Dějiny filosofie obsahují tak málo „výsledků poznáni“" právě proto, že jsou dějinami těchto smyček a zauzlení, jimiž je donucena začínat stále znovu od začátku a přitom nezpřetrhat ani jedno $\mathrm{z}$ vláken, které jí zůstaly $\mathrm{z}$ vlastních dějin, protože prèdem nemůže vědět, zda právě to jediné neobsahuje lineaturu schopnou proměnit šifry $\mathrm{v}$ text. Proto také není idea filosofického výkladu totožná s ideou nalézání smyslu: není úkolem filosofie, aby kladla jakýkoli smysl jako pozitivně daný, ani aby předkládala skutečnost jako smysluplnou, a proto hodnou obhajoby a ospravedlnění. Pravdivost hermeneutické konstrukce filosofického výkladu se osvědčuje pouze na její explorativní síle, na náhlých záblescích evidence prírodních nebo sociálních jevů, které filosofie dává řečový výraz. Z izolovaných prvků skutečnosti tak vytvárí nové druhy vzájemně související reality, které konstruuje jako nové problémové figury; ty jsou pro filosofii objektem změny, rekonstrukce skutečnosti. Změna, jak tvrdí osmadvacetiletý Adorno, zakládaje tak svou materialistickou metodu, může být jen dialektická, či být sama dialektikou. Dialektika je relace mezi výkladem skutečnosti jako konstrukcí postavenou z dílčích hádankovitých prvků reality a praktickou změnou skutečnosti jako antitezí $\mathrm{k}$ hádankovitosti; sama změněná skutečnost však ihned vyžaduje další výklad, který je „možný jen jako dialektický“ (Adorno 1990, 338). ${ }^{2} \mathrm{Z}$ toho pak může Adorno uzavrít, že aktuální je filosofie tehdy, když je činná jako dialektické myšlení.

Alain Badiou a Slavoj Žižek se setkali v roce 2004 ve Vídni, kam byli pozváni jako prèdstavitelé současného filosofického disputování $\mathrm{k}$ rozhovoru o aktuálních možnostech filosofické angažovanosti. Proč si pořadatelé této akce vybrali právě tyto dva, zůstalo veřejnosti skryto; považoval bych za možné, že oba, jakožto osoby znalé představování filosofie, méně už filosofie samotné, měli ve svých kalendáŕích s termíny entertainmentových vystoupení v mainstreamových médiích prostě volné okno. Dnes už na důvodech samožrejmě nezáleží, a pravděpodobně ani na stopě, kterou jejich sveřepý dialog ${ }^{3}$ zanechal $v$ představách poněkud pohnuté veřejnosti o současné filosofii a filosofech. Oba dobře využili př́iležitost $k$ veřejnému znázornění své myšlenkové akrobacie a slovního zakouzlování vcelku přehledných záležitostí do zkamenělých labyrintů, z nichž člověk občas marně hledá východ, protože žádný není. Badiou promluvil o své událostní filosofii v projevu pojmenovaném Myšleni události, který měl v rozhovoru stát na místě teze, Žižek nazval své expozé Filosofie není dialog a myslel je jako antitezi, poté

\footnotetext{
2 „Einzig dialektisch scheint mir philosophische Deutung möglich.“

${ }^{3}$ Němčina používá pro podobné akce výraz Streitgespräch, který naznačuje, že sice šlo o rozhovor, tedy o jednání, které zpravidla nekončí újmou na zdraví a životech, ale vedený tvrdými prostředky při obhajobě vyostřených názorů. Rozšafnost obou protagonistů by byla únosná, kdyby ji použili jako nástroj sebeironického znázornění, což jim ale evidentně na mysl nepřišlo.
} 
následovala syntéza ve formě společného rozhovoru moderovaném rakouským novinářem Clausem Phillipem. Celá tato událost je zachycena ve zmiňované knížce Filosofie a aktuálnost.

Badiou, který má zřejmě v mnoha ohledech bliž k Lyotardovi, než je na první pohled zjevné, začal úkolem filosofie, který spočívá ve vytváření problémů. Všude, kde je nutná změna úhlu pohledu, nová reflexe, vznik jiného kontextu, a tím vytvoření problému, se vyžaduje práce filosofa: vytváři se tam situace, která je filosofická tím, že myšlení, morálka, světonázor, mocenské postavení a další akcidenty vlastní jejím účastníkům nemají společná měřítka, jsou si cizí. Základ veškeré filosofie je tudíž ,filosofická situace bez měřítek“, bez možnosti srovnání, s vyloučením volby mezi dvěma (a více) opozičními stanovisky, která jako řešení odpadá proto, že opozice stojí na pojmech a argumentech bez jakékoli společné normy. Odůvodněná volba mezi tím, co se nabízí, není možná, a filosofie ji ani nehledá a neprovádí; naopak, zdůvodnění spolu s normativním žebříčkem je již výsledkem předchozího rozhodnutí (tj. volby) pro nebo proti situaci. Úkolem filosofie je dosáhnout takového rozhodnutí a vysvětlit je, Badiou říká: „Filosofická volba je moment, vkterém je volba ožrejmuje; volba, v níž jde obytí nebo o myšlení (Badiou, Zizek 2005, 18).

Když Badiou sdělí, že úkolem filosofie je rozhodovat v situacích, jejichž kontrahenty vzájemně vůbec nic nespojuje, a přitom se vyhnout svévoli okamžiku a jakékoli formě stranictví, vysvětluje vlastně, že fillosofie má jednat podle sebeurčujících pravidel. Irák a USA se dostaly do situace, která by se zpravidla charakterizovala jako politická. Protože ale splňuje kritéria filosofické situace (argumenty a postoje aktérů nic nespojuje; jsme donuceni volit mezi mírem nebo válkou, což není volba; protiválečné demonstrace dokládají distanci od hegemoniální praxe USA), tvrdí Badiou, že nejde o otázku veřejného mínění, ale o typickou „filosofickou situaci bez měřítek“. Měrítka do ní vnese filosofie prostřednictvím sebeurčujících regulí a vytvoří „problém“; filosofie totiž vytváří problémy, které se týkají celého světa (jak dobře pochopí tyhle regule, měřítka a filosofické problémy žoldácká armáda, která se rekrutuje z nižších společenských vrstev v USA, stejně jako výkvět branné moci Saddáma Husajna, tím už se Badiou nezabývá, protože vznik filosofické situace nemá vztah $\mathrm{k}$ dané situaci a jejímu řešení, ale $\mathrm{k}$ filosofii a jejímu sebezdůvodnění). To je také její hlavní rozdíl ve srovnání s politikou, jež se zaměřuje na změnu situace určitých skupin lidí.

Ve svém vystoupení vylícil Badiou své pojetí univerzality jako kategorie, v jejíchž určeních se jakoby odráží celý program jeho filosofie. ${ }^{4}$ Táž kategorie, pouze zavinutá do

\footnotetext{
${ }^{4}$ Dotyčná publikace obsahuje mj. osm tezí k univerzalitě, které Badiou uvádí jako výraz své filosofie; nebudu je zde komentovat, protože nesouvisejí tolik s prezentací aktuálnosti filosofie jako spíš se znázorněním vlastního přesvědčení. Dočteme se v nich, že událost nelze dokázat, ale jen dosvědčit; člověk je subjektem tehdy, když je takovým „dosvědčitelem události“; subjekt provádí svým svědectvím o události intervenci do řádu světa a tím činí událost viditelnou, atd. Pozoruhodná je snad
} 
plen jiných slov, má údajně podobné místo v díle psychoanalytika Žižeka. Zatímco u Badiou musí každá nerozhodnutelná disjunktivní syntéza počkat na událost, která ji rozhodne a stanoví svi̊j dosvědčující subjekt, je pro Žižeka každá disjunktivní volba špatná, protože není volbou; nevytváří nové pojmy, nové kontexty, nedává vzniknout „novému“ o sobě, pouze hromadí slova do disjunktivních syntéz bez možnosti radikální volby. Protože se v nich nevyznají, přicházejí lidé za filosofy a kladou jim otázky: „Když se nás filosofů na něco ptají, jde většinou o víc než jen otázku: veřejné mínění hledá orientaci v problematické situaci“, domnívá se Žižek (Badiou, Zizek 2005, 52). Filosofie ji má poskytovat jako radikální volbu; každá jiná cesta vede do totalitarismu. Pokud filosofie ustupuje z cesty před skutečným a radikálním rozhodnutím, přestává být filosofií a účinkuje jako „filosofická ideologie“, jejiž páteř tvoří strach před změnou. Typický př́ílad strachu ze změny vidí Žižek ve státní filosofii Jürgena Habermase: Habermas plní, co se od něj očekává, tj. schvaluje a podporuje pro kapitalistický pořádek nezbytný rozvoj vědy, poznání, techniky a hospodářství (Badiou, Zizek 2005, 59), avšak zároveň blokuje změny, které se v důsledku tohoto rozvoje objevují. Tímto způsobem zasáhl Habermas do debat o bioetice, kdy svými novokantovskými argumenty podpořil pěstování nových technologií za současného stanovení hranic, které mají zabránit tomu, aby se „nevynořila nová dimenze ,člověka“ a stará koncepce lidské důstojnosti a autonomie zůstala nedotčena“" (Badiou, Zizek 2005, 60). Musíme se smírit s tím, že filosofii je vlastní jistý vnitřní moment nehumánnosti (což není myšlenka Žižekova, ale Lyotardova, která je v oběhu přes třicet let) a bránit se před její instrumentalizací ve prospěch moralistních účelů.

V závěrečné diskusi se Badiou a Žižek shodli, že vidí filosofii velmi podobně. Jejím úkolem je vytvořit prímou spojnici mezi singulárním myšlením a univerzálností. Této vazbě, která má vzniknout, oba prrisuzují inherentní prvek nehumánnosti, což v jejich očích znamená odmítnutí či ignorování zvláštního, specifického, partikulárního. Žižek se vyjádřil otevřeně - respekt k dílčímu či dokonce důraz na něj je „reakční flašinetářství kulturních zvláštností, které je nutné porazit“ (Badiou, Zizek 2005, 73). Plodem kulturní zaměřenosti na zvláštní a snaha uznávat všechno stejným způsobem je lhostejnost - filosofie jako událost ale není lhostejná, nýbrž aktivní, je vždy pokusem o intelektuální zvládnutí toho, co je nové, avšak bez predikce důsledků, jež sebou toto „nové“ (např. revoluce, kulturní zvrat, válka) přinese. Na důsledky událostí se sice můžeme ptát, ale odpověd’ neexistuje; z toho Žižek odvozuje, že „pravý filosof žádné otázky neodpovídá, jeho úkolem je otázky vynalézat“ (Badiou, Zizek 2005, 73).

jen teze, v níž autor definuje pravdu jako materiálni stopu událostni př́měsi do situace (Wahrheit ist materielle Spur des ereignishaften Zusatzes in der Situation, s. 63); nejvíc ovšem tím, že se doslova shoduje s definicí „stopy“ (Spur) v Lévinasově díle Totalita a nekonečno a nemá daleko ani k Lyotardovi a Derridovi, aniž by uváděla zdroj. 


\section{Řeč se mluví, voda teče}

Svět je plný odpovědí, na které se neumíme správně zeptat. Naštěstí ještě přežívá živočišný druh ,pravých filosofư‘ (Žižek), který nás to má naučit a splnit tím své historické poslání. Umění správné, radikální otázky brání zániku filosofie v moralizátorství a otevírá její další a vždy novou budoucnost při ,pomáhání dnešním ženám a mužům v současné situaci‘ (Badiou). Filosofie nemá konec, protože současná situace je současná vždy jinak. ,Říká-li kdo, že nerozumí filosofii, znamená to, že nerozumí části sebe sama' (Žižek); ,dobrý filosof (Žižek) by měl umět člověku vysvětlit, že komplexita věcí je jeho vlastní komplexitou. A tak pořád dál, stranu za stranou, televizní show dvakrát do týdne, blogy, tvíty, posty, palec nahoru, palec dolů, na tom celkem nezáleží, hlavně že palec.

Největší horlitelé za aktuální filosofii, kteří mají nesrovnatelně větší možnosti dostávat filosofii do veřejného prostoru, než měli rektoři všech německých univerzit v roce 1858 dohromady, produkují ostudné řeči a vkládají je do knih, jež by mohly mít orámování z černi černější než parte. Už dávno si instrumentalizovali filosofii podle svých potřeb a schopností natolik, že si mohou dovolit brojit proti její instrumentalizaci. Podř́́dili si jazyk a vytvořili žargon, jímž se vyjadřují jako děti postižené bájnou lhavostí, a ještě pořád se najdou posluchači, kteří to mají za učenost, ne-li projevy moudrosti. Drží se paradoxů, oxymóronů, anakolutů a používají jejich překvapivý účinek jako doklad promyšlenosti a novosti svých sdělení. Vytvářejí situaci, kdy není snadné přikývnout domněnce, že všichni šašci jsou na světě proto, aby řikali ve svých zdánlivě protismyslných větách králům pravdu.

Moje subjektivní hodnocení pojednání o aktuálnosti filosofie je po prostudování několika př́kladů horší, než bylo očekávání. V jistém ohledu popsal význam a úkoly filosofie nejstř́́dměji, nejčestněji a vlastně také docela solidně nastupující rektor univerzity ve Würzburgu. Svou roli při tom nepochybně sehrál kontext; německý rektor německé univerzity s německým vzděláním filosofa byl osobou někde na rozhraní mezi centrálním mozkem lidstva a Pánembohem. Nemusel si už nic dokazovat, pocty se mu dostalo jako málokomu, s tím i prestiže, takže stačilo, aby se odvolal na to, že filosofie byla a je královnou vědění a jako taková byla, je a bude vždy aktuální sama sebou. Kdo by jinak dopomáhal speciálním vědám při přechodu od poznání $\mathrm{k}$ moudrosti a rozumění? Závěrečný odkaz na dokonalou soustavu německých univerzit není víc, než zdvořilá forma poděkování systému, jemuž sloužil a jenž ho vynesl na vrchol, takže mu bude sloužit dál. Profesor Hoffmann ukázal auditoriu, jak vypadá obrázek téměř dokonalé loajality k oboru své činnosti; kazí ho snad jen to, že k jeho následování by člověk musel mít v sobě kus germánství (ve smyslu bratří Grimmů kus staroněmeckých hodnot), a pak už jen to, že ohledně úvahy, proč se píšou pojednání o aktuálnosti filosofie, toho moc nepřináší.

V tomto smyslu je nejsdílnější Adorno, pokud prijimeme pozici, že nemluví o aktuálnosti filosofie, ale o aktuálnosti své filosofie. Takové hledisko je prijatelné a jsou př́ležitosti, kdy se dokonce vyžaduje (konkurzy, jmenovací rízení, apod.). V Adornův 
prospěch mluví navíc skutečnost, že se nestal fanatikem aktuálnosti své filosofie a nepropagoval jednu svou fixní ideu až po úroveň nejvyššího zákona všech a pro všechny. Ohledně svých očekávání od filosofie a úlohy, které by se měla podle jeho přesvědčení chopit, byl schopen změnit názor, když se změnila fakta - to znamená, byl schopen aplikovat abstraktní rozumovou koncepci filosofie na vlastní život a vlastní racionalitu. Adornův text se ovšem vi̊bec nemusel jmenovat Aktuálnost filosofie; tento název byl zvolen, jak se domnívám, čistě u dané př́ležitosti, protože nadepsat inaugurační řeč „,moje koncepce filosofie obsahuje a chci její pomocí dosáhnout ..." bylo dobově a místně zcela vyloučené.

Zůstávají poslední dva znázorňovatelé aktuálnosti filosofie, naši současníci, mediálně známí, v některých kruzích oblíbení, a to i mezi studujícími filosofie a príbuzných oborů, občas líčení jako autority současného filosofování. Filosofie si na autority př́liš nepotrpí, což je její další odlišnost od paradigmaticky vystavených věd, kde je situace mnohem vyostřenější. Filosofii charakterizuje mnohem výrazněji, že po vydání jakéhokoli, byt' sebevýznamnějšího díla s epochálním významem, ${ }^{5}$ se prvně objeví jeho kritiky, metakritiky a zpochybnění, a až mnohem později apologetiky. Filosofie je, naštěstí pro ni samotnou a pro udržení sociálního smíru, uvnitř sebe samé stále poměrně výrazně skeptická; je to ponejvíc její sebeobranná reakce na nároky a požadavky, které přicházejí zvenčí. Filosofie totiž skutečně není dialog, což je současně jedna z mála tezí Slavoje Žižeka, která trefuje do černého. Jenomže právě proto nevede ani debaty o své aktuálnosti, tak jako se nezdobí př́ílastky originální, svébytná, ojedinělá, nezávislá, svobodná, individuální, inovativní, kreativní; nevybavím si, že bych v Kantových spisech našel pokyn, jak mu rozumět, protože je aktuální, nezávislý a inovativní. Zato se z těchto výrazů stal již jakýsi epiteton constans grantových projektů na fakultách sociálních věd, sociálních studií, žurnalistiky, kulturální sebeidentifikace a genderového sjednocení. Má filosofie jakýkoli důvod, který načerpala ze své dějinné racionality, aby se družila s něčím tak zjevně nedružným, protože prázdným?

Na otázku, kdy je filosofie aktuální, je patrně jediná odpověd': když to o sobě ř́íá. A kdy to o sobě ř́ká? Obvykle tehdy, když někoho posedne myšlenka a potřebuje vyhrabat válečnou sekeru, aby ostatní o své myšlence přesvědčil. Míru aktuálnosti filosofie pak můžeme poměřovat mírou zachování morálního rozhořčení, které probudí a dokáže udržovat alespoň tak dlouho, než si ho všimnou novináři. Ve snaze být aktuální vstupuje filosofie do nedobrých spolků a odhodlává se k nedobrým krokům. Velká díla minulosti nebyla aktuální, ale velmi často dobová, situačně podmíněná. Bez vazby na žitou politickou současnost by nevznikl Hobbesův Leviatan ani Kantovo K věčnému míru; analogické impulsy se odehrávají bezesporu rovněž dnes a mohou spolupůsobit na filosofii, aby byla sociální (zachovávala si svůj vztah ke společnosti) a především politická (aby dokázala

\footnotetext{
5 Tím myslím samozřejmě Kantovy kritiky.
} 
formulovat dostatečně silné argumenty pro politickou intervenci zejména $\mathrm{v}$ takových situacích, které jiné než politické řešení nemají a vyžadují zákrok v legislativní oblasti a ve sfére hospodářské sebereprodukce globálního lidstva). Kdo napíše nějaký další Leviatan, tentokrát pro dobu, v níž se nahromadily a začínají již viditelně a nepopiratelně působit globální faktory ohrožení, u nichž lze vysledovat jedinou logiku: proměny ve faktory globálního zničení?

Tato práce čeká na člověka s vysokým vzděláním v několika klíčových oborech a se schopností vytěžit rozhodující, protože směrodatné poznatky z mezioborového srovnání situačních výzkumů; na člověka schopného najít hnisavá místa v dnešním geopolitickém uspořádání a zformulovat účinné léčebné postupy proti politice hegemonialismu, mocenského intervencionalismu, agrese jako preventivní sebeobrany a ignorování mezinárodního práva; na člověka schopného otevř́ít novou budoucnost politiky, protože z těch forem vládnutí, které se vyvinuly v různých částech světa, žádná naději na budoucnost nemá - a tu nejmenší lze přisuzovat západní liberální parlamentní demokracii, která se nezadržitelně mění před očima $\mathrm{v}$ to, čím skutečně je: $\mathrm{v}$ historickou anomálii; na člověka schopného promyslet a rozvrhnout reformu ekonomického, finančního, zdravotního a důchodového systému, bez nichž bude pokračovat jediný reformní pohyb, který je ve světě končící druhé dekády 21 . století zcela reálný: pohyb k zužování nejmajetnější globální elity a k šiření globální masy poražených, nepotřebných už dokonce pro samotné vykořistování; na člověka schopného najít prostředky, jejichž pomocí by bylo možné odolat kumulovaným environmentálním, zdravotním a politickým důsledkům soustavné a dlouhodobé likvidace př́rodního a životního prostředí, které budou přerůstat ve válečné konflikty (mj. klimatická změna, odlesňování, zanesení moří odpadem, snižování výměry zemědělsky využitelné půdy a mnoho dalších, dnes sotva patrných faktorů, kvůli nimž se jednou zvednou desítky, ne-li stamilióny lidí a vydají se na putování za obživou bez ohledu na to, zda jim budeme ř́kat ekonomičtí migranti nebo ilegální imigranti a zda stíhací letadla, kterými se je pokusíme zastrašit, budou viditelná na obrazovce radarů nebo natřená narůžovo).

Takovým člověkem by nemohl být Hobbes, poněvadž náš svět není jeho, ale naším světem; nemohl by jím být ani nějaký nový reformátor, revolucionář, spasitel, světlonoš či Vyvolený. Z pouště, kterou kolem sebe vytváříme pod záminkou, že jde o nejvyspělejší kulturu, nás nevyvede žádný nový Mojžišs; svět pomazaných zachránců již zanikl, zůstala nám uhlíkovou stopou psaná mene tekel naší doby: America First. Máme vưbec čekat na člověka tam, kde by evidentně musel přijít nadčlověk? Snad bychom mohli, protože v jádru se jedná o jeden jediný úkon, který by demokracie měla spolehlivě zvládnout, pokud by vůbec dopustila, aby se stal nezbytným: odseknout legislativu od vlivu peněz. Pro kabaret aktuálních filosofií nanejvýš nevhodný bod ve scénáři. 


\title{
Literatura
}

ADORNO, Th. W. (1990): Die Aktualität der Philosophie. In: Adorno, Th. W.: Gesammelte Schriften, Band 1: Philosophische Frühschriften. Frankfurt am Main: Suhrkamp Verlag, 325 - 344.

ANTALÍK, D. (2005): Jak srovnávat nesrovnatelné. Strategie mezináboženské komparace. Praha: Oikoymenh.

BADIOU, A., ZIZEK, S. (2005): Philosophie und Aktualität. Ein Streitgespräch. Wien: Passagen Verlag.

BURAJ, I. (2018): Manipulácia ako moc, manipulácia a sloboda. Filozofia, 73 (9), 742 - 754.

HORYNA, B. (2019): Když je filosofie aktuální. Filozofia, 74 (4), 334 - 342.

HOFFMANN, F. (1858): Über den Wert und die Bedeutung der Philosophie. Rede zum Antritte des Rectorates. Würzburg: Friedrich Ernst Thein.

LÉVINAS, E. (1961): Totalité et infini, Essai sur l'extériotité, La Haye, M. Nijhoff; český překlad Totalita a nekonečno. Esej o vnějšim. Praha: Oikoymenh 1997.

PAUER, J. (2012): Oligarchická manipulácia svetového (ne)poriadku - 1. čast'. Filozofia, 67 (9), 751 $-760$.

SZAPUOVÁ, M. (2013): K podmienkam zmysluplnej filozofickej polemiky. Filozofia, 68 (2), 151 156.

SŤAHEL, R. (2016): Environmentalizmus ako politická filozofia pre antropocén. Studia Politica Slovaca: časopis pre politické vedy, najnovšie politické dejiny a medzinárodné vzt’ahy, 9 (2), 24 $-41$.

SŤAHEL, R. (2016): Environmental Crisis and Political Revolutions. In: Arnasson, J. P. - Hrubec, M. (eds.): Social Transformations and Revolutions: Reflections and Analyses. Edinburgh: Edinburgh University Press, $99-120$.

Esej vznikla s podporou grantu VEGA č. 1/0291/18 Historicko-filozofická analýza environmentálneho myslenia, skúmanie jeho vplyvov na etické, právne a politické myslenie a jeho spoločenská odozva.

\author{
Břetislav Horyna \\ Katedra filozofie \\ Filozofická fakulta \\ Univerzita Konštantína Filozofa v Nitre \\ Hodžova 1 \\ 94974 Nitra \\ Slovenská republika \\ e-mail: bhoryna@ukf.sk
}

